\title{
STRUCTURE AND MAGNETIC PROPERTIES OF FE/SI NANOPARTICLES PREPARED BY HIGH ENERGY MILLING PROCESS
}

\author{
Muhammad Rifai ${ }^{\star}$, Yunasfi, Engkir Sukirman, Yosef Sarwanto, Mujamilah \\ Center of Science and Technology for Advanced Material, National Nuclear Energy Agency \\ Kawasan Puspiptek, Serpong, Tangerang 15314, Indonesia \\ *mrifai@batan.go.id
}

Received 06-05-2021, Revised 21-08-2021, Accepted 07-09-2021, Published 01-10-2021

\begin{abstract}
The structure and magnetic properties of $\mathrm{Fe} / \mathrm{Si}$ nanoparticles prepared by the high energy milling process have been investigated in terms of the phase transition. $\mathrm{Fe} / \mathrm{Si}$ nanoparticles were processed by high energy milling (HEM) for 10 hours to 50 hours with a weight per cent ratio of 9:1. Based on the X-ray diffraction (XRD) pattern, transmission electron microscope (TEM) observations, and vibrating sample magnetometer (VSM) analysis, the phase transition induced by HEM. The effect of structure and particle size on magnetic properties were also studied. It was found that iron and iron oxides $\left(\gamma-\mathrm{Fe}_{2} \mathrm{O}_{3} / \mathrm{Fe}_{3} \mathrm{O}_{4}\right)$ phase were exhibited on all milled samples. The magnetization value of $\mathrm{Fe} / \mathrm{Si}$ nanoparticles increased up to 20 hours with $142 \mathrm{emu} / \mathrm{gr}$ saturated magnetization and then decreased linearly with increasing milling time. Referring to the XRD result, this decline was initially caused by the iron oxide formation and magnetic interaction between iron and iron oxides nanoparticles. The phase and magnetic properties value changes related to the interaction mechanism between $\mathrm{Fe}$ atoms caused by interstitial occupied of $\mathrm{Si}$ atoms, particle size reduction, and oxidation process.
\end{abstract}

Keywords: structure, magnetic, nanoparticle, milling

\section{ABSTRAK}

Struktur dan sifat magnetik nanopartikel Fe/Si yang dibuat dengan proses milling energi tinggi telah diperiksa, dengan fokus pada transisi fasa. Nanopartikel Fe/Si diproses dengan high energy milling (HEM) selama 10 jam sampai 50 jam dengan perbandingan persen berat 9:1. Berdasarkan pola difraksi sinar-X (XRD), pengamatan mikroskop elektron transmisi (TEM), dan analisis vibrating sample magnetometer (VSM), terbukti adanya transisi fasa yang diinduksi oleh HEM. Pengaruh keadaan struktural dan ukuran partikel pada sifat magnetik seperti magnetisasi juga dipelajari. Ditemukan bahwa fasa besi dan oksida besi $\left(\gamma-\mathrm{Fe}_{2} \mathrm{O}_{3}\right.$ $\left./ \mathrm{Fe}_{3} \mathrm{O}_{4}\right)$ terlihat pada semua sampel yang digiling. Nilai magnetisasi nanopartikel $\mathrm{Fe} / \mathrm{Si}$ meningkat hingga 20 jam dengan magnetisasi jenuh $142 \mathrm{emu} / \mathrm{gr}$ dan kemudian menurun secara linier dengan bertambahnya waktu milling. Mengacu pada hasil XRD, penurunan ini awalnya disebabkan oleh pembentukan oksida besi dan interaksi magnetik antara nanopartikel besi dan oksida besi. Perubahan nilai sifat fasa dan magnet berkaitan dengan mekanisme interaksi antar atom $\mathrm{Fe}$ yang disebabkan oleh adanya interstisial atom $\mathrm{Si}$, reduksi ukuran partikel, dan proses oksidasi.

Kata kunci: struktur, magnetic, nanopartikel, milling 


\section{INTRODUCTION}

Nanomaterials have unique electrical properties, chemical and magnetic structures. It is widely used in many fields, such as data storage, applications of biosensors, and biomedical engineering ${ }^{[1]}$. One type of well-developed nanomaterial is a magnetic nanomaterial. If the size of the magnetic particles is reduced to the nanometer scale, it showed different magnetic properties, such as ferromagnetic on the bulk system, into nanometer-sized superparamagnetic particles ${ }^{[2,3]}$. Soft magnetic materials with nano-sized structures improved magnetic properties when the grain size is less than the ferromagnetic ${ }^{[4,5]}$. Magnetic nanomaterials are magnetic nanoparticles based on oxides such as $\mathrm{Fe}$ and $\mathrm{Fe}_{3} \mathrm{O}_{4}$ (magnetite), $\gamma$-Fe2O3 (maghemite) and ferrite ${ }^{[6]}$. These materials have a strong magnetic response, such as lower permeability and higher coercivity than micron-sized particles ${ }^{[7]}$, but it tends to be unstable on oxidation and thermal processes. Therefore, it is essential to modify the magnetic nanoparticles so that the nanoparticles are more stable to oxidation and thermal processes without reducing the magnetic properties significantly.

Magnetic nanoparticles of Fe-based oxide can be modified by forming nanocomposite with silica. Some research nanocomposite $\mathrm{Fe} / \mathrm{Si}$ systems showed the formation of nanoparticles are stable in biological environments and high temperature ${ }^{[8,9]}$. It has also been carried out a synthesis of $\mathrm{Fe}-\mathrm{SiO}_{2}$ nanoparticles by chemical co-precipitation technique $^{[10]}$, arc-discharge ${ }^{[11]}$, and so-gel ${ }^{[12]}$. Several methods for preparing magnetic nanoparticle materials have been developed by physical technique ${ }^{[13-15]}$.

The large size starting materials can be scaled down to nano-size by this technique, such as the high energy milling (HEM) method ${ }^{[16]}$. HEM is a process with a mutual collision between the balls and the powders (material) and a convenient technique to produce alloy powders from elemental powders. Non-equilibrium solid solution phases and nanocrystalline microstructures can be produced by this technique ${ }^{[17]}$. This process crushed powders into fragments. The milled powders are characterized based on the initial powders, milling speed, and time ${ }^{[18]}$. This process can be modified and added to another element to obtain higher material properties. The objective of this research is to study the influence of milling time on the structure and magnetic properties of nanoparticles of $\mathrm{Fe} / \mathrm{Si}$ using the HEM technique in terms of particle size.

\section{METHOD}

Materials Fe (Sigma Aldrich, 97\%, CAS\# 7439-89-6) and Si (Sigma Aldrich, 99.998\% 7440-21-3) powders were mixed with $\mathrm{Fe}: \mathrm{Si}=9: 1$ composition and a total weight of 10 grams. Powders mixture were milled with different milling times 10, 20,30, 40 and 50 hours by SPEX CertiPrep 8000M Mixer/Mill at speed $1485 \mathrm{rpm}$ in the argon atmosphere. The milling vial was sealed with a flexible O-ring to reduce oxidation. The milling process was stopped for 1.8 hours after every 5.4 hours of milling for cooling purposes. Powder samples were taken from the selected milling time for analysis and characterization.

The powder samples were observed by a JEOL 1200 transmission electron microscope (TEM) at $120 \mathrm{kV}$ to obtain particle size and structure. It was also analyzed by Phillips PW1107 X-ray diffraction (XRD) equipment using $\mathrm{CuK} \alpha$ radiation.

The peak position, half-maximum width, and material phase were obtained by the XRD (3rd generation Empyrean, Malvern Panalytical) measurements, and it was analyzed by the Hanawalt method. Magnetic parameters were measured by vibrating sample magnetometer (VSM), with a range of external magnetic field of \pm 1 Tesla at room 
temperature, gain acceleration and 0.25 Tesla per minute of reduction of the external magnetic field.

\section{RESULTS AND DISCUSSION}

A TEM bright-field image of a particle of Fe/Si powder after milling 10, 20, 30, 40 and 50 hours, as seen in Figures 1. The corresponding selected area diffraction pattern (SADP) pattern shows the body-centred cubic (BCC) $\alpha$-Fe structure in all TEM micrographs. The spherical Fe and elongated Si powder were observed with a particle size of about $30 \mathrm{~nm}$.
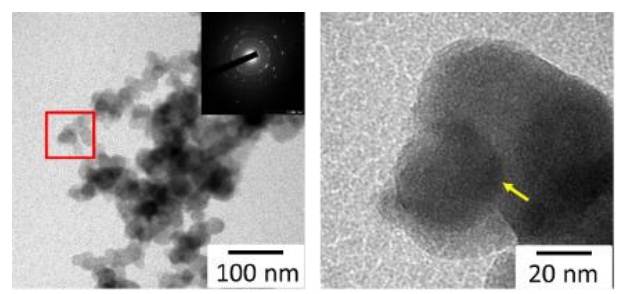

(a)
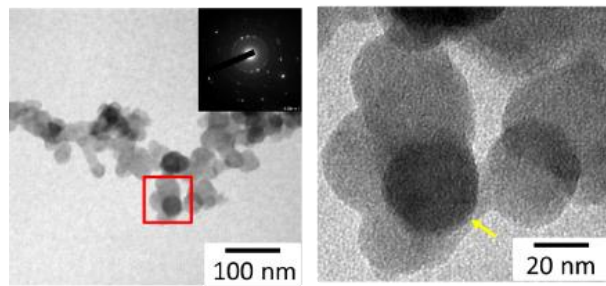

(b)
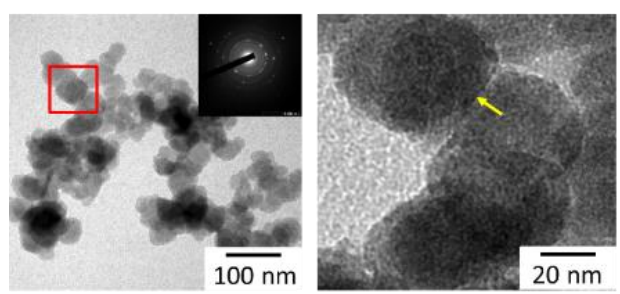

(c)
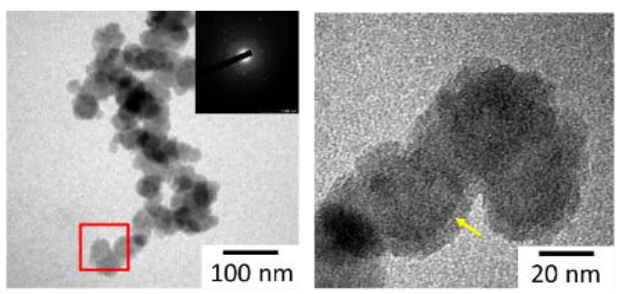

(d)
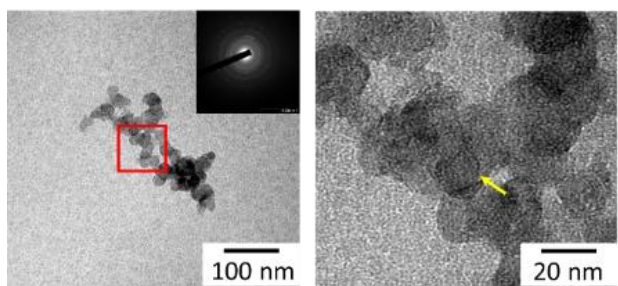

(e)

Figure 1. TEM micrograph for (a) 10 hours, (b) 20 hours, (c) 30 hours, (d) 40 hours, (e)50 hours. 
The particles structure after 20 hours of the milling time were irregular and distributed over a wide range particle size. After 40 hours, the particles have become smaller and appear near-spherical shape. The particles appearance were different in size, and the shape became uniform and rounded shape with increasing the milling time.

XRD data of the Fe/Si milled powders are shown in Figure 2. This data was analyzed by qualitative analysis Hanawalt method ${ }^{[19]}$, and it gave information about the possibility of the iron oxide formation $\left(\mathrm{Fe}_{3} \mathrm{O}_{4} / \gamma-\mathrm{Fe}_{2} \mathrm{O}_{3}\right)$ with increasing milling time. This qualitative method analyzed each diffraction data by angle diffraction $(2 \theta)$ and relative intensity (Ir). These data are registered from the largest to the smallest value for the diffraction line. Diffraction pattern data can be obtained $2 \theta, d(\AA)$ and $\operatorname{Ir}$ as seen in Table. 1 .

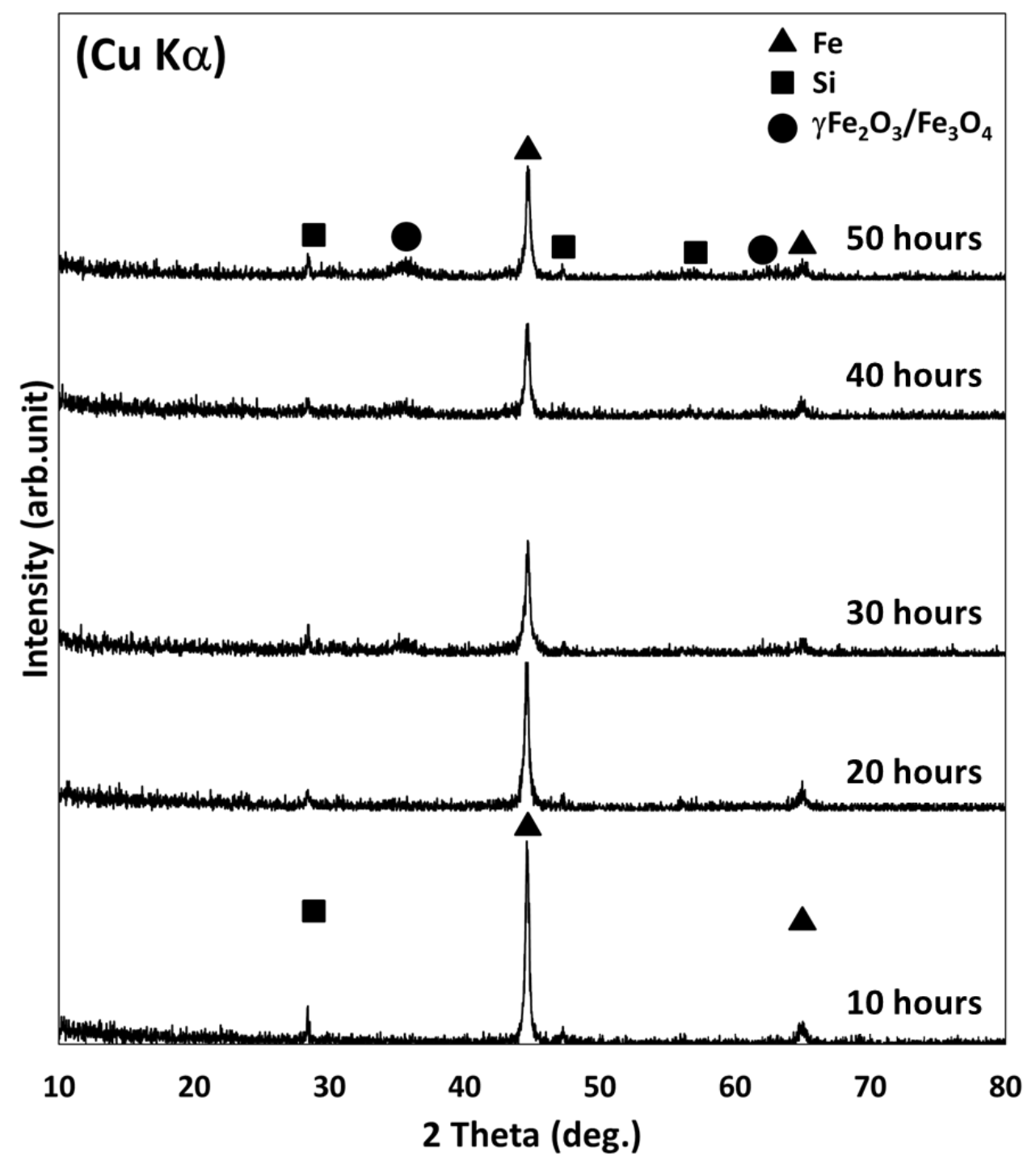

Figure 2. X-ray diffraction pattern of Fe/Si powder after milling 10, 20, 30, 40 and 50 hours

The diffraction intensity of Fe/Si milled powder was diminished on peaks and widened. This appearance means the crystalline size of $\mathrm{Fe} / \mathrm{Si}$ milled powder becomes smaller than Fe and Si powder. The XRD results were analyzed by Origin software and obtained 
diffraction angle $(2 \theta$,$) and full width at half maximum (FWHM), which is indicated by the$ $\beta$ value for each phase $\mathrm{Fe}$, as shown in Table 2 . By using the Scherrer equation ${ }^{[19]}$, the average crystalline size can be calculated based on the width of the diffraction peaks:

$$
\mathrm{D}=(0.9 \cdot \lambda) /(\beta \cdot \cos \theta)
$$

$D$ is the crystalline size, $\mathrm{Cu}-\mathrm{K} \alpha$ is the wavelength (15.404 nm), $\beta$ is an FWHM, in radians and $\theta$ is diffraction angle. Based on the above equation, the average crystalline size of the milling time can be seen in Table 2. The FWHM of Fe peaks increases with the increase of milling time that indicates refining particles. This result can be seen in the shifts in diffraction angle, which enabled the calculation of crystalline size changes with milling time. Due to the milling process on $\mathrm{Fe} / \mathrm{Si}$ powders at a different time, the crystalline size decreases up to 40 hours milling time. After 50 hours of milling time, the crystalline size increased, most likely due to the formation of the crystalline growth of Fe powders.

Table 1.The diffraction angle, d-spacing, and relative intensity of Fe/Si milled powder.

\begin{tabular}{|c|c|c|c|c|}
\hline Sample & $2 \theta$ & $d(\AA)$ & $I_{r}(\%)$ & Remarks \\
\hline Fe/Si & 28.40 & 3.14 & 19 & $\mathrm{Si}$ \\
\hline \multirow{2}{*}{ (10 hours) } & 44.58 & 2.03 & 100 & $\mathrm{Fe}$ \\
\hline & 65.08 & 1.43 & 2,5 & $\mathrm{Fe}$ \\
\hline Fe/Si & 28.40 & 3.14 & 14 & $\mathrm{Si}$ \\
\hline \multirow[t]{2}{*}{ (20 hours) } & 44.66 & 2.02 & 100 & $\mathrm{Fe}$ \\
\hline & 64.96 & 1.43 & 20 & $\mathrm{Fe}$ \\
\hline $\mathrm{Fe} / \mathrm{Si}$ & 28.40 & 3.14 & 22 & $\mathrm{Si}$ \\
\hline \multirow[t]{5}{*}{ (30 hours) } & 35.54 & 2.52 & 12 & $\gamma \mathrm{Fe}_{2} \mathrm{O}_{3} / \mathrm{Fe}_{3} \mathrm{O}_{4}$ \\
\hline & 44.66 & 2.02 & 100 & $\mathrm{Fe}$ \\
\hline & 47.22 & 1.92 & 14 & $\mathrm{Si}$ \\
\hline & 62.80 & 1.47 & 11 & $\gamma \mathrm{Fe}_{2} \mathrm{O}_{3} / \mathrm{Fe}_{3} \mathrm{O}_{4}$ \\
\hline & 65.20 & 1.42 & 12 & $\mathrm{Fe}$ \\
\hline $\mathbf{F e} / \mathrm{Si}$ & 28.40 & 3.14 & 22 & $\mathrm{Si}$ \\
\hline \multirow[t]{5}{*}{ (40 hours) } & 35.70 & 2.51 & 22 & $\gamma \mathrm{Fe}_{2} \mathrm{O}_{3} / \mathrm{Fe}_{3} \mathrm{O}_{4}$ \\
\hline & 44.68 & 2.02 & 100 & $\mathrm{Fe}$ \\
\hline & 47.34 & 1.91 & 16 & $\mathrm{Si}$ \\
\hline & 62.28 & 1.48 & 13 & $\gamma \mathrm{Fe}_{2} \mathrm{O}_{3} / \mathrm{Fe}_{3} \mathrm{O}_{4}$ \\
\hline & 64.88 & 1.43 & 24 & $\mathrm{Fe}$ \\
\hline $\mathrm{Fe} / \mathrm{Si}$ & 22.04 & 4.02 & 14 & $\mathrm{SiO}_{2}$ \\
\hline \multirow[t]{5}{*}{ (50 hours) } & 28.44 & 3.13 & 20 & $\mathrm{Si}$ \\
\hline & 35.80 & 2.50 & 17 & $\gamma \mathrm{Fe}_{2} \mathrm{O}_{3} / \mathrm{Fe}_{3} \mathrm{O}_{4}$ \\
\hline & 44.58 & 2.03 & 100 & $\mathrm{Fe}$ \\
\hline & 47.22 & 1.92 & 13 & $\mathrm{Si}$ \\
\hline & 62.90 & 1.47 & 11 & $\gamma \mathrm{Fe}_{2} \mathrm{O}_{3} / \mathrm{Fe}_{3} \mathrm{O}_{4}$ \\
\hline
\end{tabular}


Table 2. The diffraction angle. FWHM and crystallite size of Fe/Si milled powders.

\begin{tabular}{ccccc}
\hline $\begin{array}{c}\text { Milling time } \\
\text { (hours) }\end{array}$ & $\mathbf{2 \theta}$ & Cos $2 \boldsymbol{\theta}$ & $\begin{array}{c}\text { FWHM } \\
(\boldsymbol{\beta})\end{array}$ & $\mathbf{D}$ \\
\hline 10 & 44.622 & 0.92914 & 0.27195 & 32.9962 \\
20 & 44.580 & 0.92528 & 0.30147 & 29.7607 \\
30 & 44.629 & 0.92511 & 0.33049 & 27.1524 \\
40 & 44.626 & 0.92512 & 0.41426 & 21.4878 \\
50 & 44.628 & 0.92512 & 0.31575 & 28.4197 \\
\hline
\end{tabular}

XRD data of the samples for different milling times exhibited a clear indication of the changes in the material. The milled powder showed peaks of the three elements but, after 10 and 20 hours, only the $\mathrm{Fe}$ and $\mathrm{Si}$ were exhibited. This occurrence means no detectable reactions during the milling to produce any intermetallic compounds and that $\mathrm{Si}$ has dissolved in the Fe matrix. XRD data could be attributed to the substitutional dissolution of $\mathrm{Si}$ in the $\alpha$-Fe lattice since the atomic radius of $\mathrm{Si}(0.118 \mathrm{~nm})$ is smaller than that of $\mathrm{Fe}$ $(0.123 \mathrm{~nm})^{[20]}$. The crystalline size of $\mathrm{Fe} / \mathrm{Si}$ became even more negligible than $\mathrm{Fe} / \mathrm{Si}$ because the amount of Si dissolved is more significant ${ }^{[18]}$.

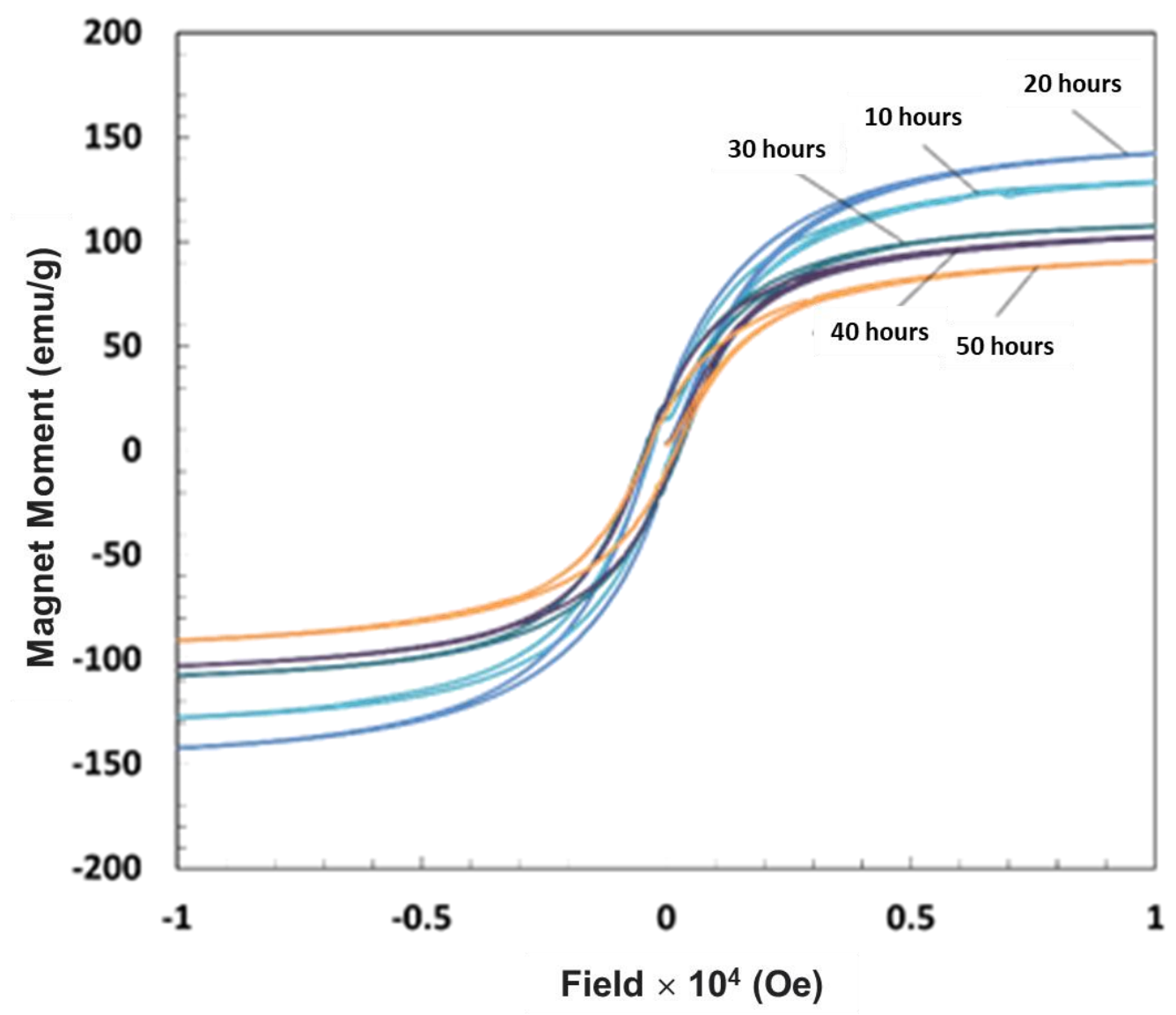

Figure 3. Magnetic hysteresis (M-H) curve measurement results on samples of Fe/Si milled powder. 
Table 3. Magnetic parameter of Fe/Si milled powders.

\begin{tabular}{cccc}
\hline \multirow{2}{*}{$\begin{array}{c}\text { Milling time } \\
\text { (hours) }\end{array}$} & \multicolumn{3}{c}{ Magnetic parameter } \\
\cline { 2 - 4 } & $\begin{array}{c}\mathbf{M}_{\mathbf{s}} \\
(\mathbf{e m u} / \mathbf{g})\end{array}$ & $\begin{array}{c}\mathbf{M}_{\mathbf{r}} \\
(\mathbf{e m u} / \mathbf{g})\end{array}$ & $\begin{array}{c}\mathbf{H}_{\mathbf{c}} \\
(\mathbf{O e})\end{array}$ \\
\hline $\mathbf{1 0}$ & 128.9293 & 17.6145 & 198 \\
$\mathbf{2 0}$ & 142.0172 & 22.0943 & 257 \\
$\mathbf{3 0}$ & 107.3369 & 22.8738 & 354 \\
$\mathbf{4 0}$ & 102.0372 & 22.1424 & 277 \\
$\mathbf{5 0}$ & 90.8423 & 16.7083 & 250 \\
\hline
\end{tabular}

Magnetic hysteresis (M-H) curve measurement results on samples of Fe/Si milled powder with different milling time is shown in Figure 3. The curve shows the magnetization value that increases with increasing milling time up to 20 hours and decreases linearly with increasing milling time. It is very closely related to the particle size of the material. The smaller the particle size of the material, has higher the saturated magnetization $(M s)$ value. Referring to the XRD data, the milling time for 10 and 20 hours formed only the primary Fe phase with the lower intensity peak. It suggests that the crystalline size becomes smaller due to the mutual collision between the powders and ball mill. After 30 and 40 hours of milling time, the $M s$ value becomes lower due to the iron oxide formation that influences the magnetic interaction between the iron particles. In comparison, 50 hours milling time showed the smallest $M s$ value due to the formation of iron powder agglomeration.

Results of the M-H hysteresis curve shows several magnetic parameters, such as $M s$, remanence magnetization $(\mathrm{Mr})$ and coercive field $(\mathrm{Hc}) . \mathrm{Ms}$ value is the maximum value of the magnetic field that can be generated by the material (peak value of hysteresis curve), $M r$ is the value of the magnetic field at the moment when the polarization $=0$, and $H c$ is the polarization moment when the magnetic field $=0$ divided by 2 . The results of the M-H analysis are shown in Table 3. An increase in the $H c$ value materials demonstrated the possibility of a pinning effect on the rotation of the magnetic moment ${ }^{[21]}$. In addition to the factors mentioned above, the large surface anisotropy and surface roughness of the powders can contribute to their large $\mathrm{Hc}$ compared to that of the $\mathrm{Fe} / \mathrm{Si}^{[22]}$. Furthermore, the effect of milling on the $\mathrm{Fe} / \mathrm{Si}$ powders may cause mechanical stress and dislocation, which affected the mechanical properties and is related to the magnetic properties of materials. Hence, the particle size refinement plays a leading role in increasing $\mathrm{Hc}$ in that stage, as seen in Figure 1.

\section{CONCLUSION}

The effect of milling time on the structure and magnetic properties of Fe-Si was studied in terms of phase transition. The particles appearance were different in size, and the shape became uniform and rounded with increasing milling time. The XRD result showed that the milling time up to 20 hours, which is formed only primary iron phase. In contrast, an increase in milling time up to 50 hours showed an increase in minor phase of iron oxide 
$\left(\mathrm{Fe}_{3} \mathrm{O}_{4} / \gamma-\mathrm{Fe}_{2} \mathrm{O}_{3}\right)$ and diminished primary iron phase. The particle size refinement showed a significant role in increasing the coercive field.

\section{ACKNOWLEDGEMENT}

Research work funded DIPA FY 2015 at Center for Science and Technology of Advanced Material, National Nuclear Energy Agency of Indonesia.

\section{DAFTAR PUSTAKA}

1 Wang, S., Cao, H., Gua, F., Li, C., Huang, G. 2008. Synthesis and Magnetic Properties of Iron/Silica Core/Shell Nanostructures. Journal of Alloys and Compounds, 457, 560564.

2 Caizer, C. 2003. Saturation Magnetization of $\square$-Fe2O3 Nanoparticle Dispersed in a Silica Matrix. Physica B, 327, 27-33.

3 Lopez, P. G., Silvetti, P.S. 2004. Effects of Milling Time on Fe/SiO2 System Prepared by Mechanical Alloying. Physica B, 354, 141-40.

4 McHenry, M.E., Willard, M.A., Laughlin, D.E. 1999. Progress Material Science, 44, 291.

5 Yoshizawa, Y., Oguma, S., Yamauchi, K. 1988. Journal Applied Physics, 64, 6044.

6 Vatta, L.L., Sanderson, D.R., R. K. Koch, R.K. 2006. Magnetic Nanoparticles: Properties and Potential Applications. Pure Applied Chem, 78, 1793-1801.

7 Yu, M., Xu, Y., Mao, Q., Li, F., \& Wang, C. 2016. Electromagnetic and absorption properties of nano-sized and micro-sized Fe4N particles. Journal of Alloys and Compounds, 656, 362-367.

8 Abdellaoui, M., Gaffet, E., 1992. Journal Physics III , 2, 73.

9 Elsukov, E.P., Konygin, G.N., Barinov, V.A., Coronina, E.V. 1992. Journal Physics: Condens. Matter, 4, 7597.

10 Tie, S.L., Lee, H.C., Bae, Y.S., Kim, M.B., Lee, K., Lee, C.H. 2007. Monodisperse Fe3O4/Fe@SiO2 Core/Shell Nanoparticles with Enhanced Magnetic Property. Colloids and Surfaces A: Physicochemical Engineering Aspects, 293, 278-285

11 Zhang, X.F., Dong, X.L., Huang, H., Lv, B., Zhu, X.G., Lei, J.P., Ma, S., Liu, W., Zhang, Z.D. 2007. Synthesis, Structure, and Magnetic Properties of SiO2-Coated Fe Nanocapsules. Materials Science and Engineering A, 454-455, 211-215.

12 Tang, N.J., Jiang, H.Y., Zhong, W., Wu, X.L., Zou, W.Q., Du, Y.W. 2006. Synthesis and Magnetic Properties of $\mathrm{Fe} / \mathrm{SiO} 2$ Nanocomposites Prepared by So-Gel Method Combined with Hydrogen Reduction. Journal Alloys and Compounds, 419, 145-148.

13 Guo, Z., Shin, K., Korki, B.A., Young, P.D., Kaner, B.R., Hahn, H.T. 2009. Fabrication and Characterization of Iron Oxide Nanoprticles Filled Polypyrrole nanocomposite. Journal Nanoparticle Research, 11, 401-1452.

14 Todaka, Y., Nakamura, M., Hattori, S., Tsuchiya K., Umemoto, M. 2003. Synthesis of Ferrite Nanoparticles by Mechanochemical Processing Using a Ball Mill. Materials Transactions, 44, 277 - 284. 
15 Khitouni, N., Daly, R., Escoda, L., Llorca-Isern, N., Suñol, J. J., Dammak, M., \& Khitouni, M. 2020. The Effect of B and Si Additions on the Structural and Magnetic Behavior of Fe-Co-Ni Alloy Prepared by High-energy Mechanical Milling. Journal of Superconductivity and Novel Magnetism, 33, 2727-2735.

16 Gubin, P.S., Kohoursharov, A.Y., Khomutov, B.G., Yurkov, Y.G. 2005. Magnetic Nanoparticles: Preparation, Structure and Properties. Russian Chemical Reviews, 74, 489-520.

17 Koch, C.C. 1993. Nanostructure Materials, 2, 109.

18 Mujamilah., Grace, TJ. S. Engkir, S., Yosef, S., Eko, Y.P., 2012. Struktur dan Sifat Magnetic Nanopartikel Magnetic (Fe-R) $(\mathrm{R}=\mathrm{Fe}, \mathrm{Tb}, \mathrm{Dy}, \mathrm{Co})$ dari Hasil Proses Milling Energy Tinggi. Jurnal Sains Materi Indonesia, 13, 159-167.

19 Cullity, B.D. 1956. Element of X-ray diffraction. Addison-Wesley, Metalurgy Series, USA., 297-323.

20 Tennent, R.M. 1971. Science Data Book. Oliver \& Boyd, Hong Kong, 56-59.

21 Desia, I., Fetreza, C.S., Bujdosob, L., Brozc, J., Baloghc, A.G. 2010. Mechanical Alloying of $\mathrm{Fe}-\mathrm{Si}$ and Milling of $\alpha$ - and $\beta$-FeSi2 Bulk Phases. Journal of Alloys and Compound 508, 51-54B.

22 Joint Committee for Powder Diffraction Standard (JCPDS), File no. 60696. 